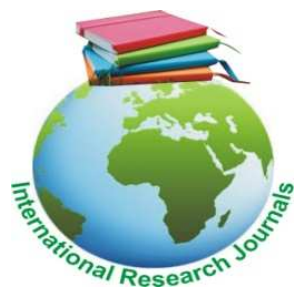

Journal of Medicine and Medical Sciences Vol. 8(1) pp. 020-024, March 2017

Available online http://www.interesjournals.org/JMMS

DOI: http:/dx.doi.org/10.14303/jmms.2017.015

Copyright (C) 2017 International Research Journals

Full Length Research Paper

\title{
Biochemical changes investigated by psoroptic mange infestation in buffaloes
}

\author{
${ }^{1 *}$ Mervat E.I. Radwan, ${ }^{2}$ Reham Samir E., ${ }^{3}$ Mohamed Abd-EIAziz M. \\ ${ }^{1}$ Infectious Diseases Department with Veterinary Hospital, Faculty of Veterinary Medicine \\ ${ }^{2}$ Parasitology Department, Faculty of Veterinary Medicine, Benha University, Moshtohor, Toukh, 13736, Egypt \\ ${ }^{3}$ Physiology Department, Faculty of Veterinary Medidine, Assuit University, New valley, Egypt \\ ${ }^{*}$ Corresponding Author's E-mail: Dr_Mervat19@yahoo.com
}

\begin{abstract}
The present study was executed on fifty buffaloes (Bubalusbubalus), aged 1-3years, suffering from signs of pruritus and alopecia throughout the period from January to December 2015. Upon parasitological enquiry, they were proved to be infested by Psoroptes species. The changes in the serobiochemical parameters were compared in two groups, infested group and non infested healthy group, each of 30 buffaloes. The following parameters were assessed: serumtotal protein (TP), serum albumin (ALB), blood urea nitrogen (BUN), creatinine levels, serum enzymatic activities levels as glutamic-pyruvic transaminase (GPT), glutamic oxaloacetic transaminase (GOT), alkaline phosphastase (ALP), and lactate dehydrogenase (LDH), Oxidative and anti oxidative biomarkers as malondialdehyde (MDA), Glutathione S-transferase (GST), superoxide dismutase (SOD) and catalase (CAT), inflamatory parameters as C- reactive protein (CRP), pro inflammatory cytokines (IL6) and tumor necrosis factor (TNF). The results concluded a significant difference in the serum constituents $(P<0.05)$ between the infested buffaloes and the non-infestedones.
\end{abstract}

Keywords: Psorobtic mange, Oxidant and antioxidant bio markers, CRP and enzymatic changes.

\section{INTRODUCTION}

Psoroptic mites are imperative etiological causes of mange that have a significant economic impact among wild and domesticated ungulates (Syed, 2009). They are non-burrowing mites that inhabit the superficial layer of the skin and by means of their mouthparts, they actively abrades and scrapes the epidermis rather than piercing it (Bates 1999; Van Den Broek and Huntley, 2003). Mainly, Psoroptic mange seems to be one of the highly important skin affections of buffaloes in tropical countries, where the disease is highly widespread and contagious, transmits among animals by direct and indirect contact resulting in outbreaks (Radostits et al., 2007; Jones et al., 2008). It results in increasingthe fattening time in the herd, decreasing daily weight gain, destructing the hides and causing sporadic mortalities (Lonneux et al. 1998; Rehbein et al., 2002).

Among dairy cattle, the milking process is hampered and the milk yield is decreased due to the restlessness effectof the parasite (Schoett et al., 2002). The disease produce by animals acariasis is not restricted topically to the skin but can leads to a generalized illness that affects the different tissues of the animal and causes severe cell damage due to the biochemical changes induced (Shang, et al; 2014).

In Egypt, Psoroptes sp. is highly prevailing among buffaloes in Nile Delta (El-Khodery et al., 2009); however, the risky consequences of the psorotptic infestation, the changes in the biochemical parameters, oxidant/ antioxidant and inflammatory markers are stillunobvious. I the identification of these risk factors assist the practitioner to establish the most proper control programmers (El-Khoderyet al., 2010).

Therefore, the aim of this study is to recognize of biochemical changes associated with psoroptic infestation by serum analysis of different biochemical constituent as TP, ALB, BUN, creatinine, GPT, GOT, 
ALP, and LDH, MDA, GST, SOD, CAT, CRP, IL6 and TNF.

\section{MATERIAL AND METHODS}

\section{Animals}

Fifty buffaloes, aged 1-3 years suffering from pruritus and alopecia were admitted to Benha education hospital in faculty of veterinary medicine, Benha University throughout the period from January to December 2015. They were proved to be infested by Psoroptes sp. upon screening of skin scraps.

\section{Skin scraping}

Psoroptic infestations were diagnosed by microscopic inspection of superficial scrapings of the skin which were obtained from different areas of the body. On the edge of active cutaneous lesion, glycerin was applied and the scrapings were done using a scalpel. The collected scraps were located in closed tubes. Ten percent of potassium hydroxide $(\mathrm{KOH})$ was added to the scrapings, the sediment was spreadon a glass slide, microscopically examined underx10 magnification and identified according to Soulsby (1986).

\section{Animal grouping for sero-biochemical assessment}

A total of 60 buffaloes were grouped into Positive and negative group, each of 30 animals. The infested group was chosen from the psoroptic infested buffaloes. Whereas, the healthy group wereselected apparently healthy and wereproved to be free from any infection by cautious clinical and parasitological examination.

\section{Blood sampling and serum preparation}

Ten $\mathrm{ml}$ of blood was collected from the jugular vein of each buffaloe using dry syring and poured on the wall of non heparinized tubes. The blood samples were left to stand in a slant position for 30- 60 minutes at room temperature for clotting. The clotted blood was centrifuged at 3,000 rpm for 10 min for complete serum separation; all the sera were stored at $-20^{\circ} \mathrm{C}$ till further analysis (Tuck et al., 2009).

\section{Biochemical assessment}

Estimation of biochemical changes was done by analyzing the serum samples of the animals in each group for serum total protein (TP), serum albumin (ALB), blood urea nitrogen (BUN) levels, serum enzymatic activities levels as glutamic--pyruvic transaminase (GPT), glutamic oxaloacetic transaminase (GOT), Alkaline phosphastase (ALP), and lactate dehydrogenase (LDH) using high performance liquid chromatography method (HPLC, Sykam 1125 pump system, Germany) (Miller and Yang, 1985; Zaspel and Csallany, 1983; Reynolds and Judd, 1984).

Moreover, spectrophotometric method using commercial kits (bio-diagnostic, Egypt) was used for measuring oxidative and anti oxidative biomarkers (serum malondialdehyde (MDA), glutathione-Stransferase (GST), superoxide dismutase (SOD), catalase (CAT) and the inflammatory biomarkers (CRP, IL6 and TNF).

\section{Statistical analysis}

The statistics was applied by means of SPSS soft ware (SPSS ver. 16, Inc., Chicago, IL). T-test was used for each groupat a significant value at $p<0.05$ (Steel, 1997).

\section{RESULTS}

Buffaloes infested with psoroptic mage manifested apparent loss of body weight, emaciation, severe itching, the buffaloes attempted to rub the infested areas of the body againt walls and fences, alopecia, crust formation and exudation (Figure. 1. A-C). Psoroptic mites had a tendency to attack the longhaired areas of the body, wither, the back, head of the tail or the entire parts of the body in sever infestation. The positively infested buffaloes revealed the presence of psoroptic mites upon microscopic examination of skin scraps (Figure. 1. D- F).

In table 1 , the biochemical assessment revealed that TP and ALB were efficiently $(P<0.001)$ decreased $(6.18$ \pm 0.25 and $3.46 \pm 0.22$ respectively) among infested buffaloes as compared with the healthy ones. An elevation in the level of enzyamatic activity among infested buffaloes which was expressed by high significant levels of GPT $(77.80 \pm 5.95)$ and GOT (142.6 \pm 11.17), ALP (129.0 \pm 6.01) and LDH (137.2 \pm 10.66). A noticed increase of BUN and cretainin (56.20 \pm 3.81 and $1.99 \pm 0.23)$ levels was also recorded due to psoroptic infestation.

The oxidative stress biomarkers, CAT, GST and SODactivities were declined from $50.00 \pm 4.10,241.0 \pm$ 26.24 and $41.00 \pm 3.51$ in healthy animals to $24.80 \pm$ $3.48,107.6 \pm 26.71$ and $16.00 \pm 1.30$ in infested animals. Conversely, the level of MDA was significantly activated to160.4 \pm 7.51 . The inflammatory biomarkers as CRP, IL6 and TNF were significantlyraised to $10.70 \pm 0.82$, $84.6 \pm 3.86$, and $123.4 \pm 5.30$ correspondingly in the infested group. 
022 J. Med. Med. Sci.

Table 1. Serum biochemical changes induced by psoroptic mange

\begin{tabular}{|c|c|c|}
\hline Bio chemical parameters & Positive group Mean $\pm S E$ & Negative group \\
\hline TP & $6.18 \pm 0.25^{\pi \times x}$ & $8.463 \pm 0.22$ \\
\hline ALB & $3.46 \pm 0.22^{\cdots}$ & $4.545 \pm 0.17$ \\
\hline \multicolumn{3}{|l|}{ GPT } \\
\hline & $77.80 \pm 5.95^{\star * *}$ & $18.75 \pm 2.29$ \\
\hline GOT & $142.6 \pm 11.17^{\mathrm{mx}}$ & $56.50 \pm 5.33$ \\
\hline ALP & $129.0 \pm 6.01^{\mathrm{mx}}$ & $20.25 \pm 3.57$ \\
\hline LDH & $137.2 \pm 10.66^{\pi \pi x}$ & $43.50 \pm 4.27$ \\
\hline BUN & $56.20 \pm 3.81^{x \times x}$ & $24.50 \pm 2.66$ \\
\hline CREATININE & $1.99 \pm 0.23^{* * *}$ & $0.52 \pm 0.04$ \\
\hline CAT & $24.80 \pm 3.48^{\pi x}$ & $50.00 \pm 4.10$ \\
\hline \multicolumn{3}{|l|}{ GST } \\
\hline SOD & $16.00 \pm 1.30^{\pi \times \pi}$ & $41.00 \pm 3.51$ \\
\hline MDA & $160.4 \pm 7.51^{\pi \times \pi}$ & $64.50 \pm 4.25$ \\
\hline CRP & $10.70 \pm 0.82^{\star \star}$ & $5.743 \pm 0.34$ \\
\hline IL6 & $84.6 \pm 3.86^{\pi \times \pi}$ & $81.50 \pm 5.36$ \\
\hline TNF & $123.4 \pm 5.30^{\pi \times}$ & $33.25 \pm 2.06$ \\
\hline
\end{tabular}

${ }^{* *}$ Value of $p<0.01$ and ${ }^{* * *}$ value of $p<0.001$

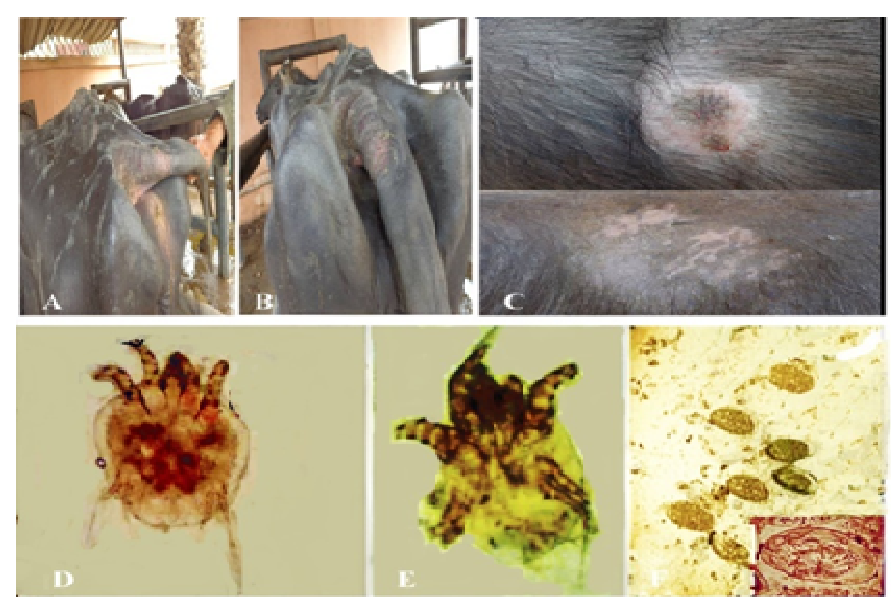

Figure 1. A-C Alopecia and skin crusts due to psoroptic mange in different parts of the body , D,E Psoroptes mites obtained by skin scraping, F. Eggs of mites ( magnified X40 at lower right corner)

\section{DISCUSSION}

The Infested buffaloes in the contemporary study suffered from loss of body weight, emaciation, itching where the buffaloes attempted to rub the infested areas of the body against the walls and fences, alopecia, crusts 
formation and exudation. These findings came in agreement with Vishe et al., (2012) and Syed (2009). The significant decrease in TP and ALB levels and the increase in CRP levels among infested buffaloes were considered good markers of inflammation induced by mites. The elevation of cytokines levels in response to such inflammation stimulated the liverto retort by producing a great number of positive acute-phase proteins and reducing the production negative acutephase ones (Abbass et al; 2012) as Albumin and some other protein. The physiological interpretation for decreasing of negative proteins synthesis is mostly to save and protect amino acids for forming positive acutephase proteins more competently (Chua et al., 1999). Whereas, CRP is considered positive acute phase protein which serves different physiological functions for the immune system as a part of innate immunity (Herpers et al; 2009).

Moreover, the free radicals produced during psoroptes infestation caused protein oxidation and DNA impairment (Allaam et al., 2014;Kanbur 2008 ; Dimri 2008).In this study, buffaloes with psoroptic mange were found in an oxidative stress condition which was indicated by decreased SOD,CAT and GST activities and high MDA level. The inflammation induced by psoroptic mange among infested buffaloes activated the inflammatory cells, which recruit macrophages and neutrophils with reactive oxygen substance, as hypochlorite, hydrogen peroxide $\left(\mathrm{H}_{2} \mathrm{O}_{2}\right)$ and oxygen radicals. These substances show forceful cytotoxic effects on the parasites (Gurgoze et al., 2003). Both catalase and SOD had a combating effect on the produced oxidative stress. The over consumption of SOD was attributed to its activity to counter the free radicals created during the infestation (Beigh et al., 2014).

Moreover, SOD plays a role in catalyzing the super oxidedismutation to hydrogen peroxide ( $\left.\mathrm{H}_{2} \mathrm{O} 2\right)$ and oxygen. The over utilization of SOD leads to an increase in $\mathrm{H} 2 \mathrm{O} 2$ level in the cells. Subsequently, CAT activity is consumed in neutralizing $\mathrm{H} 2 \mathrm{O} 2$ produce (Clemen and Waller, 1987).

Similarly, the severe exhaustion of antioxidant system could explain the decreased GST activity encountered in this study (Kocyigit et al., 2005). The early phase of libeartion of pro inflammatory cytokine due to psoroptic infestation led to elevation of lipid peroxides and hence the level of MDA increased. The significant change in BUN, GPT, GOT, ALP, and LDH among infested buffaloes were previously recorded by Allaam et. al.,(2014) who attributed this change to the increase of poisonous product of oxidative stress in circulation which have a systematic effect on other tissues than the skin. The elevation of cytokines (IL-6, TNF) levels as compared with healthy group maybe accredited to the severe allergic inflammatory condition induced by Psoroptes mange which stimulated the release of already secreted and newly synthesized cytokines and contributed to the parasite pathology (Majewska et al., 2016). Mainly, TNF plays an important role in in linking adaptive and innate immunity in chronic inflammatory disease (Pasparakis et al; 1996) and extreme secretion of TNF is related to the vulnerability to allergies (Stanley and Lacy, 2010). Such release of cytokines or inflammatory factors can exacerbates the condition by extra activation of the immune system (Shang et al., 2013).

\section{CONCLUSION}

Though psoroptic mites commence as a topical disease, it has the ability to persuade changesin the tissue activities, inflammatory reaction and the oxidant/antioxidant stability of animals with the progression of the illness which may lead to systemic disease. This was expressed well in our study, where there were significant changes between psoroptic infested and healthy groups in the levels of protein , albumindifferent enzymes(GPT, GOT, ALP, and LDH) oxidative stree factors (MDA, GST, SOD, CAT) and inflammatory biomarkers (CRP, IL6 and TNF). Therefore, these are highly endorsed to be used as bioindicator of the tissue reaction, inflammatory status and oxidative stress inpsoroptic infestation.

\section{REFERENCES}

Abbas A, Lichtman A, Pillai S (2012). Basic immunology Functions and Disorders of the Immune System (4th ed., p. 40). Philadelphia, PA: Saunders/Elsevier.

Allaam AM, Allam ST, Elkhatam OA (2014). Biochemical and Circulating Oxidative Stress Biomarkers in Egyptian Buffaloes (Bubalusbubalis) Infested by Sarcoptic Mange, Global Veterinaria, 13 (4): 656-661

Bates PG (1999). Inter- and intra-specific variation within the genus Psoroptes (Acari: Psoroptidae). Vet Parasitol, 83: 201-217.

Bates PG (1999). Inter- and intra-specific variation within the genus Psoroptes (Acari: Psoroptidae). Vet Parasitol, 83 :201-217.

Chua E, Clague JE, Sharma AK, Horan MA, Lombard M (1999). Serum transferrin receptor assay in iron deficiency anaemia and anaemia of chronicdisease in the elderly. QJM, 92 (10): 587-94.

Dimri U, Sharma MC, Swarup D, Ranjan R, Kataria M (2008). Alterations in hepatic lipid peroxides and antioxidant profile in Indian water buffaloes from sarcoptic mange. Res Vet Sci , 85:101-105.

El-Khodery AS, Osman AS, Ishii M, Al-Gaabary HM ( 2010). Risk factors of infestation by Psoroptes spp. mites in buffalo (Bubalusbubalis) at smallholder farms in the Nile Delta region, EgyptTropAnim Health Prod, 42:275-281.

Gurgoze SY, Sahin T, Sevgili M, Ozkutlu Z, Ozan ST (2003). The effects of ivermectin or doramectin treatment on sone antioxidant enzymes and the level of lipid peroxidation in sheep with natural sarcopticscap.Yuzuncu YII Universitesi Veteriner Fakultesi Dergisi, 14: $30-34$.

Herpers B L, Endeman H, De Jong BAW, De Jongh BM, Grutters JC, Biesma DH, Van Velzen-Blad H (2009). Acute-phase responsiveness of mannose-binding lectin in community-acquired pneumonia is highly dependent upon MBL2 genotypes. ClinExplmmunol, 156(3):488-94.

Jones J, Jenkins T, Webb I, Davies A, Bates P (2008). Psoroptic mange 
in cattle in south Wales. Vet Rec, 162: 460.

Kanbur M, Atalay O, Ica A, Eraslan G, Cam Y (2008).The curative and antioxidative efficiency of doramectin and doramectin + vitamin $A$, $D_{3}$, E treatment on Psoroptescuniculi infestation in rabbits. Res Vet Sci. 2008, 85: 291-293.

Kocyigit A, Keles H, Selek S, Guzel S, Celik H, Kovacic P, Cooksy A (2005).Unifying O. Erel, 2005. Increased DNA damage and oxidative mechanism for toxicity and addiction by abused stress in patients with cutaneous leishmaniasis.drugs: electron transfer and reactive oxygen species. Mutat. Res., 585(1-2): 71-78.

Lonneux JF, Nguyen TQ, Detry J, Farnir F, Losson BJ (1998). The relationship between parasite counts, lesions, antibody titres and daily weight gains in Psoroptesovis infested cattle. Vet Parasitol, 76:137-148.

Majewska A, Gajewska M, Dembele K, Maciejewski H, Prostek A, Jank M (2016). Lymphocytic, cytokine and transcriptomic profiles in peripheral blood of dogs with atopic dermatitis .BMC Veterinary ResearchBMC, 12:174.

Miller KW, Yang CS (1985). An isocratic high-performance liquid chromatography method for the simultaneous analysis of plasma retinol, a-tocopherol and various carotenoids. Anal Biochem, 145: 21- 26.

Pasparakis M, Alexopoulou L, Episkopou V, Kollias G (1996). Immune and inflammatory responses in TNF alpha-deficient mice: a critical requirement for TNF alpha in the formation of primary $B$ cell follicles, follicular dendritic cell networks and germinal centers, and in the maturation of the humoral immune response. J Exp Med. 184(4):1397-411.

Radostits OM, Gay CC, Hinchcliff KW, Constable PD (2007). Veterinary Medicine. 10th edn., Elsevier Saunders, London, UK.

Rehbein S, Visser M, Winter R, Maciel AE (2002). Efficacy of a new long-acting formulation of ivermectin and other injectibleavermectins against Psoroptesovis infestation in cattle. Parasitology Research, $88: 1061-1065$.

Reynolds SL, Judd HJ (1984). Rapid procedure for the determination of vitamins $A$ and $D$ in fortified skimmed milk powder using highperformance liquid chromatography. Analyst,109: 489-492.

Schoett S, Wieim G, Ichmann G (2002). Eradication of chorioptic mange in two dairy farms.XXII World Buitatrics Congress, 18-23 August, Hanover, Germany.

Shang XF, Miao XL, Wang DS, Li JX, Wang XZ, Yan ZT, Wang CM,

Wang He XR, Pan $H$ (2013). Acaricidal activity of extracts from Adonis coeruleaMaxim.againstPsoroptescuniculi in vitro and in vivo. Vet Parasitol, 195:136-141.

Shang X, Wang D, Miao X, Wang X, Li1 J, Yang Z, Pan1H (2014). The oxidative status and inflammatory level ofthe peripheral blood of rabbits infested with Psoroptescuniculi The oxidative status and inflammatory level ofthe peripheral blood of rabbits infested with Psoroptes cuniculi, Parasites \& Vectors 7:124
Soulsby E (1986). Helminths, arthropods and protozoa of domestic animals, 7 edn. Bailliere $M$. Tindall, London.

Stanley AC, Lacy P (2010).Pathways for cytokine secretion. Physiology (Bethesda), 25(4):218-29.

Steel R, Torrie J, Dickey D (1997). Principles and procedures of Statistics: A Biometrical Approach, 3rd ed., McGraw-Hill, New York, NY.

Syed A, Irshad K, Azhar M, Muhammad TT, Abeera N, Adeela A, Muhammad TAJ (2009).Treatment of dairy buffaloes naturally infected with sarcopticmange Parasit Dis, 33(1\&2):54-56

Tuck M, Chan WD, Chia D, Godwin KA, Grizzle EW, Krueger EK, Rom W, Sanda M, Sorbara L, Stass S, Wang W, Brenner ED (2009). Standard Operating Procedures for Serum and Plasma Collection: Early Detection Research Network Consensus Statement Standard Operating Procedure Integration Working Group. J Proteome Res, 8(1): 113-117.

Van den Broek AH, Huntley JF.Sheep scab: the disease, pathogenesis and control. J Comp Pathol. 2003 Feb-Apr;128(2-3):79-91.

Vishe H P, Awar K P, Gupta HK, Rao G S (2012). Prevalence and hemato-biochemical studies in parasitic and non parasitic dermatological disorders in Surti buffalo and buffalo calves, Vet World, 5(4): 230-235

Zaspel BJ, Csallany S (1983). Determination of alpha-tocopherol in tissues and plasma by high-performance liquid chromatography. Anal Biochem, 130: 146-150. 